\title{
Penerapan Metode Simple Additive Weighting(SAW) Untuk Pemilihan Siswa Terbaik
}

\author{
Ahmad Setiadi*1, Yunita 2 , Anisa Ratna Ningsih ${ }^{3}$ \\ 1,2Program Studi Manajemen Informatika, AMIK BSI Karawang, Program Studi Teknik Informatika, STMIK Nusa \\ Mandiri Jakarta, Program Studi Sistem Informasi, STMIK Nusa Mandiri Jakarta

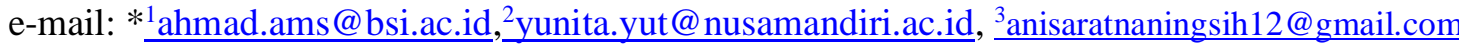

\begin{abstract}
Abstrak - Pada penelitian ini penulis bertujuan untuk merancang serta membangun sebuah sistem penunjang keputusan pada Madrasah Ibtidaiyah Tarbiyatul Mu'alimi Al-Wasliyah atau sering disebut MI TAMMAS, Metode yang penulis gunakan adalah metode Simple Additive Weighting(SAW). Terdapat lima kriteria yang penulis gunakan yaitu Berakhlak baik, Aktif di dalam kelas, Nilai Raport tertinggi dan Absensi kehadira. Penggunaan Sistem Pendukung Keputusan (SPK) diharapkan dapat membantu keputusa yang diambil dalam memilih dan menentukan siapakah yang menjadi siswa terbaik, mengingat selama ini tidak digunakan metode tertentu dalam memilih siswa sehingga terkadang keputusan dianggap kurang objective dan tidak tepat sasaran. Pada penelitian ini akan diangkat suatu kasus yaitu mencari alteratif terbaik berdasarkan kriteria-kriteria yang telah ditentukan dengan menggunakan metode Simple Additive Weighting (SAW). Penelitian dilakukan dengan mencari nilai bobot untuk setiap atribut, kemudian dilakukan proses perankingan yang akan menentukan alteratif yang optimal, yaitu siswa terbaik.
\end{abstract}

\section{Kata kunci- SAW, Simple Additive Weighting, SiswaTerbaik}

\section{PENDAHULUAN}

Madrasah Ibtidaiyah Tarbiyatul Mu'alimi Al-Wasliyah yang berlokasi di Kalideres-Jakarta Barat mempunyai tujuan yang mulia yaitu menciptakan generasi muslim yang beriman, bertakwa, berakhlak mulia, berkualitas dan mampu mengembangkan potensi yang dimilikinya, guna terwujudnya Madrasah yang berkualitas dan berwawasan Islam. Namun hingga saat ini Madrasah Ibtidaiyah Tarbiyatul Mu'alimi Al-Wasliyah atau sering disebut MI TAMMAS belum mempunyai metode khusus dalam memilih siswa terbaik. Dengan adanya masalah diatas dengan adanya sistem Pendukung keputusan Pemilihan Siswa Terbaik dengan metode Simple Additive Weighting (SAW) pada Madrasah Ibtidaiyah TAMMAS, Kalideres Jakarta Barat diharapkan dapat membantu dalam pemilihan siswa terbaik.

Metode SAW merupakan salah satu metode penyelesaian masalah Multi Attribute Decision Making (MADM) yang paling sederhana dan paling banyak digunakan. Selain itu, metode ini juga merupakan metode yang paling mudah diaplikasikan, karena mempunyai algoritma yang tidak terlalu rumit. Metode SAW sering juga dikenal istilah metode penjumlahan terbobot. Konsep dasar metode SAW adalah mencari penjumlahan terbobot dari rating kinerja pada setiap alternatif pada semua atribut [1]. Berdasarkan permasalahan tersebut, perlu dibangun sebuah sistem pendukung keputusan untuk mendukung proses pemilihan siswa berprestasi di Madrasah Ibtidaiyah TAMMAS. Sistem pendukung keputusan (SPK) adalah sistem berbasis komputer yang menyajikan dan memproses informasi yang memungkinkan pembuatan keputusan menjadi lebih produktif, dinamis, dan inovatif[2]

\section{METODE PENELITIAN}

Metode penelitian ini menggunakan Simple Additive Weighting (SAW) menurut Kusumadewi dalam [3] Metode SAW adalah metode penjumlahan terbobot. Konsep dasar dari metode SAW adalah mencari pejumlahan terbobot dari rating kinerja pada setiap alternatif pada semua atribut. Metode SAW membutuhkan proses normalisasi matrik keputusan (X) ke skala yang dapat diperbandingkan dengan semua rating alternatif yang ada. Adapu langkah penyelesaian suatu masalah menggunakan metode Simple Additive Weighting yaitu: 
1. Menentukan kriteria yang akan dijadikan acuan dalam pengambilan keputusan, yaitu $\mathrm{C}_{\mathrm{i}}$.

2. Memberikan nilai bobot untuk masing-masing kriteria sebagai $\mathrm{W}$.

3. Memberikan nilai rating kecocokan setiap alternatif pada setiap kriteria.

4. Membuat matriks keputusan berdasarkan kriteria $\left(\mathrm{C}_{\mathrm{i}}\right)$, kemudian melakukan normalisasi matriks berdasarkan persamaan yang disesuaikan degan jenis atribut (atribut keuntungan ataupun atribut biaya) sehingga diperoleh matriks ternormalisasi $\mathrm{R}$.

$R_{i j}$
$=\left\{\begin{array}{l}\frac{x_{i j}}{M a x_{i} x_{i j}} \text { JIKA J ADALAH ATRIBUT KEUNTUNGAN (BENEFIT) } \\ \frac{\operatorname{Min}_{i} x_{i j}}{x_{i j}} \text { JIKA J ADALAH ATRIBUT BIAYA (COST) }\end{array}\right.$

Gambar 1. Rumus Ternormalisasi

Keterangan Setiap kriteria:

$\begin{array}{cc}\mathrm{R}_{\mathrm{ij}} & \text { : nilai rating kinerja ternormalisasi. } \\ \mathrm{X}_{\mathrm{ij}} & \text { : nilai atribut yang dimiliki dari } \\ \operatorname{Max}_{\mathrm{ij}} & \text { : nilai terbesar dari setiap kriteria. } \\ \text { Min } \mathrm{X}_{\mathrm{ij}} & \text { : nilai terkecil dari setiap kriteria. } \\ \text { Benefit } & \text { : jika nilai terbesar adalah terbaik } \\ \text { Cost } & \text { : jika nilai terkecil adalah terbaik }\end{array}$

5. Hasil akhir diperoleh dari proses perankingan yaitu penjumlahan dan perkalian matriks ternormalisasi $\mathrm{R}$ dengan vektor bobot sehingga diperoleh nilai terbesar yang dipilih sebagai alternatif yang terbaik $\left(\mathrm{A}_{\mathrm{i}}\right)$ sebagai solusi.

$$
V i=\sum_{j=1}^{n} W_{j} R_{i j}
$$

Gambar 2.

Rumus Perankingan

Keterangan:

$\mathrm{V}_{\mathrm{i}} \quad$ : ranking untuk setiap alternatif.

$\mathrm{W}_{\mathrm{j}} \quad$ : nilai bobot dari setiap kriteria.

\section{HASIL DAN PEMBAHASAN}

Langkah langkah untuk menetukan perhitungan untuk memilih siswa terbaik menggunakan metode Simple Additive Weighting (SAW), yaitu:

\section{Menentukan Kriteria}

Langkah kesatu (1) menentukan kriteria yang akan digunakan sebagai acuan dalam pemilihan siswa terbaik yaitu $\mathrm{C}_{\mathrm{i}}$

Tabel 1. Tabel Ketentuan Kriteria

\begin{tabular}{|c|c|}
\hline $\begin{array}{c}\text { Kode Kriteria } \\
\left(\mathrm{C}_{\mathrm{i}}\right)\end{array}$ & Ketentuan Kriteria \\
\hline $\mathrm{C}_{1}$ & Berakhlak baik \\
\hline $\mathrm{C}_{2}$ & Aktif di dalam kelas \\
\hline $\mathrm{C}_{3}$ & Nilai raport tertinggi \\
\hline $\mathrm{C}_{4}$ & Absensi kehadiran \\
\hline $\mathrm{C}_{5}$ & Bertanggug jawab \\
\hline
\end{tabular}

Nilai setiap alternatif $A_{i}$ pada setiap kriteria yang sudah ditentukan. Nilai tersebut diperoleh berdasarkan nilai crisp: $\mathrm{i}=1,2, \ldots \ldots, \mathrm{m}$ dan $\mathrm{j}=1,2, \ldots \ldots, \mathrm{n}$.

Adapun kriteria pembobotan yang dilakukan penulis dalam penelitian pemilihan siswa terbaik, yaitu sebagai berikut:

a. Kriteria Berakhlak Baik

Variabel Berakhlak Baik terbagi atas 5 bilangan fuzzy, yaitu:

Sangat Rendah (SR)

Rendah (R)

Sedang (S)

Tinggi (T)

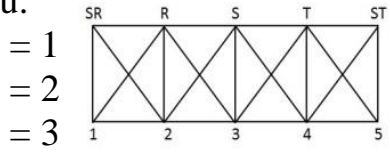

Sangat Tinggi $(\mathrm{ST}) \quad=5$

b. Kriteria Aktif di Dalam Kelas

Variabel Berakhlak Baik terbagi atas 5 bilangan fuzzy, yaitu:

Sangat Rendah (SR)

Rendah (R)

Sedang $(\mathrm{S})$

Tinggi (T)

Sangat Tinggi (ST)

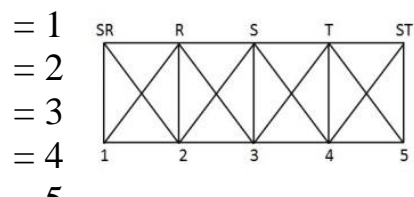

c. Kriteria Nilai Raport Tertinggi

Variabel Berakhlak Baik terbagi atas 5 bilangan fuzzy, yaitu:

Sangat Rendah (SR)

Rendah (R)

Sedang (S)

Tinggi (T)

$=1$

$=2$

$=3$

$=4$

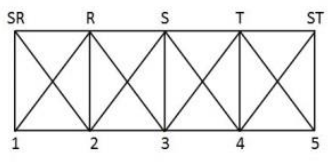

Sangat Tinggi $(\mathrm{ST}) \quad=5$

d. Kriteria Absensi Kehadiran

Variabel Berakhlak Baik terbagi atas 5 bilangan fuzzy, yaitu:

Sangat Rendah (SR)

Rendah (R)

Sedang (S)

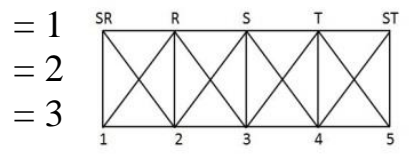


Tinggi ( $\mathrm{T})$

$$
=4
$$

Sangat Tinggi (ST)

$$
=5
$$

e. Kriteria Bertanggung Jawab

Variabel Berakhlak Baik terbagi atas 5 bilangan fuzzy, yaitu:

Sangat Rendah (SR)

Rendah (R)

Sedang (S)

Tinggi $(\mathrm{T})$

Sangat Tinggi (ST)

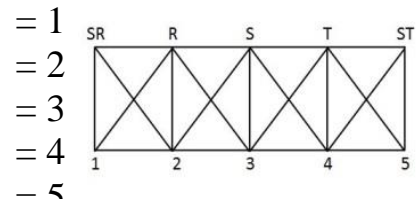

\section{Memberikan Nilai Bobot}

Langkah kedua (2) memberikan nilai bobot atau tingkat kepentingan (W) setiap kriteria. Bobot kriteria yang akan digunakan dalam memilih siswa terbaik adalah sebagai berikut

Tabel 2.

Tabel Bobot Preferesi (W) Setiap Kriteria

\begin{tabular}{|c|c|c|}
\hline $\begin{array}{c}\text { Kode } \\
\text { Kriteria }\end{array}$ & Ketentuan Kriteria & $\begin{array}{c}\text { Bobot } \\
\text { Preferensi } \\
(\mathbf{W})\end{array}$ \\
\hline $\mathrm{C}_{1}$ & Berakhlak baik & $0,30(30 \%)$ \\
\hline $\mathrm{C}_{2}$ & Aktif di dalam kelas & $0,15(15 \%)$ \\
\hline $\mathrm{C}_{3}$ & Nilai raport tertinggi & $0,15(15 \%)$ \\
\hline $\mathrm{C}_{4}$ & Absensi kehadiran & $0,20(20 \%)$ \\
\hline $\mathrm{C}_{5}$ & Bertanggug jawab & $0,20(20 \%)$ \\
\hline
\end{tabular}

\section{Memberi Nilai Rating}

Langkah ketiga (3) menentukan rating kecocokan setiap alternatif pada setiap kriteria kemudian memodelkannya ke dalam bilangan fuzzy setelah itu konversikan ke bilangan Crips.Seperti terlihat pada tabel IV.3 yang telah ditentukan sebagai berikut:

Tabel 3.

Tabel Rating Kecocokan dari Setiap Alternatif pada Setiap Kriteria

\begin{tabular}{|c|c|c|c|c|c|}
\hline \multirow{2}{*}{ Alternatif } & \multicolumn{5}{|c|}{ Kriteria } \\
\cline { 2 - 6 } & $\mathbf{C}_{\mathbf{1}}$ & $\mathbf{C}_{\mathbf{2}}$ & $\mathbf{C}_{\mathbf{3}}$ & $\mathbf{C}_{\mathbf{4}}$ & $\mathbf{C}_{\mathbf{5}}$ \\
\hline $\mathrm{A}_{\mathbf{1}}$ & 3 & 3 & 3 & 5 & 4 \\
\hline $\mathrm{A}_{2}$ & 3 & 3 & 3 & 4 & 3 \\
\hline $\mathrm{A}_{3}$ & 3 & 4 & 4 & 3 & 4 \\
\hline $\mathrm{A}_{4}$ & 4 & 4 & 4 & 4 & 3 \\
\hline
\end{tabular}

\begin{tabular}{|c|c|c|c|c|c|}
\hline \multirow{2}{*}{ Alternatif } & \multicolumn{5}{|c|}{ Kriteria } \\
\cline { 2 - 6 } & $\mathbf{C}_{\mathbf{1}}$ & $\mathbf{C}_{\mathbf{2}}$ & $\mathbf{C}_{\mathbf{3}}$ & $\mathbf{C}_{\mathbf{4}}$ & $\mathbf{C}_{\mathbf{5}}$ \\
\hline $\mathrm{A}_{5}$ & 2 & 3 & 3 & 4 & 4 \\
\hline $\mathrm{A}_{6}$ & 5 & 4 & 5 & 5 & 5 \\
\hline $\mathrm{A}_{7}$ & 3 & 4 & 4 & 4 & 4 \\
\hline $\mathrm{A}_{8}$ & 3 & 4 & 4 & 5 & 4 \\
\hline $\mathrm{A}_{9}$ & 3 & 4 & 4 & 4 & 4 \\
\hline $\mathrm{A}_{10}$ & 4 & 2 & 3 & 4 & 3 \\
\hline $\mathrm{A}_{11}$ & 3 & 2 & 3 & 4 & 4 \\
\hline $\mathrm{A}_{12}$ & 3 & 3 & 3 & 4 & 5 \\
\hline $\mathrm{A}_{13}$ & 4 & 4 & 3 & 3 & 4 \\
\hline $\mathrm{A}_{14}$ & 3 & 4 & 5 & 4 & 5 \\
\hline $\mathrm{A}_{15}$ & 3 & 4 & 3 & 4 & 4 \\
\hline $\mathrm{A}_{16}$ & 3 & 2 & 3 & 4 & 4 \\
\hline $\mathrm{A}_{17}$ & 3 & 2 & 3 & 4 & 4 \\
\hline $\mathrm{A}_{18}$ & 2 & 3 & 4 & 5 & 5 \\
\hline $\mathrm{A}_{19}$ & 4 & 4 & 5 & 5 & 5 \\
\hline $\mathrm{A}_{20}$ & 2 & 3 & 3 & 3 & 3 \\
\hline $\mathrm{A}_{21}$ & 4 & 3 & 3 & 4 & 4 \\
\hline $\mathrm{A}_{22}$ & 4 & 3 & 3 & 4 & 4 \\
\hline $\mathrm{A}_{23}$ & 3 & 3 & 4 & 5 & 5 \\
\hline $\mathrm{A}_{24}$ & 3 & 2 & 3 & 4 & 3 \\
\hline $\mathrm{A}_{25}$ & 2 & 3 & 3 & 3 & 4 \\
\hline $\mathrm{A}_{26}$ & 3 & 3 & 3 & 4 & 4 \\
\hline $\mathrm{A}_{27}$ & 4 & 4 & 3 & 2 & 3 \\
\hline $\mathrm{A}_{28}$ & 5 & 5 & 5 & 5 & 5 \\
\hline & 4 & 4 & 4 & 3 & 4 \\
\hline & & 3 & 4 & 4 \\
\hline
\end{tabular}

\section{Membuat Matriks Keputusan dan Normalisasi}

Setelah nilai rating alternatif pada setiap kriteria ditentukan langkah keempat (4) adalah pembentukan matriks keputusan $(\mathrm{X})$ yang dibentuk dari tabel rating kecocokan dari setiap alternatif pada setiap kriteria.Nilai $\mathrm{X}$ setiap alternatif $\left(\mathrm{A}_{\mathrm{i}}\right)$ pada setiap kriteria $\left(\mathrm{C}_{\mathrm{i}}\right)$ sudah ditentukan.Matriks yang dihasilkan sebagai berikut: 
Jurnal SISFOKOM, Volume 07, Nomor 02, September 2018

$\left[\begin{array}{lllll}3 & 3 & 3 & 5 & 4 \\ 3 & 3 & 3 & 4 & 3 \\ 3 & 4 & 4 & 3 & 4 \\ 4 & 4 & 4 & 4 & 3 \\ 2 & 3 & 3 & 4 & 4 \\ 5 & 4 & 5 & 5 & 5 \\ 3 & 4 & 4 & 4 & 4 \\ 3 & 4 & 4 & 5 & 4 \\ 3 & 4 & 4 & 4 & 4 \\ 4 & 2 & 3 & 4 & 3 \\ 3 & 2 & 3 & 4 & 4 \\ 3 & 3 & 3 & 4 & 5 \\ 4 & 4 & 3 & 3 & 4 \\ 3 & 4 & 5 & 4 & 5 \\ 3 & 4 & 3 & 4 & 4 \\ 3 & 2 & 3 & 4 & 4 \\ 3 & 2 & 3 & 4 & 4 \\ 2 & 3 & 4 & 5 & 5 \\ 4 & 4 & 5 & 5 & 5 \\ 2 & 3 & 3 & 3 & 3 \\ 4 & 3 & 3 & 4 & 4 \\ 4 & 3 & 3 & 4 & 4 \\ 3 & 3 & 4 & 5 & 5 \\ 3 & 2 & 3 & 4 & 3 \\ 2 & 3 & 3 & 3 & 4 \\ 3 & 3 & 3 & 4 & 4 \\ 4 & 4 & 3 & 2 & 3 \\ 5 & 5 & 5 & 5 & 5 \\ 4 & 4 & 4 & 3 & 4 \\ 2 & 3 & 3 & 4 & 4\end{array}\right]$

Di bawah ini adalah hasil pengujian dimana nilai awal diproses menggunakan metode Simple Additive weighting (SAW) dan mendapatkan nilai hasil akhir dalam perhitungan seperti di atas, berikut tabel hasil pengujian di bawah ini

Tabel 4. Tabel Hasil Pengujian

\begin{tabular}{|c|c|c|c|c|c|c|c|}
\hline \multirow[b]{2}{*}{ No } & \multirow[b]{2}{*}{ Nama Siswa } & \multicolumn{5}{|c|}{ Kriteria } & \multirow[b]{2}{*}{ Hasil } \\
\hline & & $\begin{array}{c}\text { Be } \\
\text { ra } \\
\text { kh } \\
\text { lak } \\
\text { Ba } \\
\text { ik }\end{array}$ & $\begin{array}{c}\text { Akti } \\
\text { f di } \\
\text { Dal } \\
\text { am } \\
\text { Kel } \\
\text { as }\end{array}$ & $\begin{array}{c}\text { Nila } \\
\text { i } \\
\text { Rap } \\
\text { ort } \\
\text { Tert } \\
\text { ingg } \\
\text { i }\end{array}$ & $\begin{array}{c}\text { Abs } \\
\text { ensi } \\
\text { Keh } \\
\text { adir } \\
\text { an }\end{array}$ & $\begin{array}{c}\text { Berta } \\
\text { nggu } \\
\text { ng } \\
\text { jawa } \\
\text { b }\end{array}$ & \\
\hline 1 & $\begin{array}{c}\text { Arwan } \\
\text { Sarifuddin }\end{array}$ & $\begin{array}{c}0,1 \\
8\end{array}$ & 0,09 & 0,09 & 0,20 & 0,16 & 0,72 \\
\hline 2 & $\begin{array}{c}\text { Dhani } \\
\text { Febriyan }\end{array}$ & $\begin{array}{c}0,1 \\
8\end{array}$ & 0,09 & 0,09 & 0,16 & 0,12 & 0,64 \\
\hline 3 & $\begin{array}{c}\text { Dina } \\
\text { Bombom } \\
\text { Anto }\end{array}$ & $\begin{array}{c}0,1 \\
8\end{array}$ & 0,12 & 0,12 & 0,12 & 0,16 & 0,70 \\
\hline 4 & $\begin{array}{c}\text { Galih } \\
\text { Prastiyo }\end{array}$ & $\begin{array}{c}0,2 \\
4\end{array}$ & 0,12 & 0,12 & 0,16 & 0,12 & 0,76 \\
\hline 5 & Ibnu Baihaqi & $\begin{array}{c}0,1 \\
2\end{array}$ & 0,09 & 0,09 & 0,16 & 0,16 & 0,62 \\
\hline
\end{tabular}

\begin{tabular}{|c|c|c|c|c|c|c|c|}
\hline \multirow[b]{2}{*}{ No } & \multirow[b]{2}{*}{ Nama Siswa } & \multicolumn{5}{|c|}{ Kriteria } & \multirow[b]{2}{*}{ Hasil } \\
\hline & & $\begin{array}{c}\text { Be } \\
\text { ra } \\
\text { kh } \\
\text { lak } \\
\text { Ba } \\
\text { ik }\end{array}$ & $\begin{array}{c}\text { Akti } \\
\text { f di } \\
\text { Dal } \\
\text { am } \\
\text { Kel } \\
\text { as }\end{array}$ & $\begin{array}{c}\text { Nila } \\
\text { i } \\
\text { Rap } \\
\text { ort } \\
\text { Tert } \\
\text { ingg } \\
\text { i }\end{array}$ & $\begin{array}{c}\text { Abs } \\
\text { ensi } \\
\text { Keh } \\
\text { adir } \\
\text { an }\end{array}$ & $\begin{array}{c}\text { Berta } \\
\text { nggu } \\
\text { ng } \\
\text { jawa } \\
\text { b }\end{array}$ & \\
\hline 6 & Indah Pratiwi & $\begin{array}{c}0,3 \\
0\end{array}$ & 0,12 & 0,15 & 0,20 & 0,20 & 0,97 \\
\hline 7 & $\begin{array}{c}\text { Kevin } \\
\text { Hovandra } \\
\text { Riswandy }\end{array}$ & $\begin{array}{c}0,1 \\
8\end{array}$ & 0,12 & 0,12 & 0,16 & 0,16 & 0,74 \\
\hline 8 & $\begin{array}{c}\text { M. Maulana } \\
\text { Saifurrahman }\end{array}$ & $\begin{array}{c}0,1 \\
8\end{array}$ & 0,12 & 0,12 & 0,20 & 0,16 & 0,78 \\
\hline 9 & $\begin{array}{c}\text { Maulisa } \\
\text { Darata Putri }\end{array}$ & $\begin{array}{c}0,1 \\
8\end{array}$ & 0,12 & 0,12 & 0,16 & 0,16 & 0,74 \\
\hline 10 & $\begin{array}{c}\text { Nabil } \\
\text { Abyakta } \\
\text { Zufar }\end{array}$ & $\begin{array}{c}0,2 \\
4\end{array}$ & 0,06 & 0,09 & 0,16 & 0,12 & 0,67 \\
\hline 11 & $\begin{array}{c}\text { Nabilah } \\
\text { Nusaibah }\end{array}$ & $\begin{array}{c}0,1 \\
8\end{array}$ & 0,06 & 0,09 & 0,16 & 0,16 & 0,65 \\
\hline 12 & $\begin{array}{l}\text { Nadila Eka } \\
\text { Ramadhani }\end{array}$ & $\begin{array}{c}0,1 \\
8\end{array}$ & 0,09 & 0,09 & 0,16 & 0,20 & 0,72 \\
\hline 13 & $\begin{array}{c}\text { Nanda } \\
\text { Salsabila }\end{array}$ & $\begin{array}{c}0,2 \\
4\end{array}$ & 0,12 & 0,09 & 0,12 & 0,16 & 0,73 \\
\hline 14 & $\begin{array}{l}\text { Ramadhani } \\
\text { Septiawan }\end{array}$ & $\begin{array}{c}0,1 \\
8\end{array}$ & 0,12 & 0,15 & 0,16 & 0,20 & 0,81 \\
\hline 15 & $\begin{array}{l}\text { Romadhoni } \\
\text { Fairuz }\end{array}$ & $\begin{array}{c}0,1 \\
8\end{array}$ & 0,12 & 0,09 & 0,16 & 0,16 & 0,71 \\
\hline 16 & $\begin{array}{l}\text { Sandy Setia } \\
\text { Alamsyah }\end{array}$ & $\begin{array}{c}0,1 \\
8\end{array}$ & 0,06 & 0,09 & 0,16 & 0,16 & 0,65 \\
\hline 17 & $\begin{array}{l}\text { Zidan A } \\
\text { Aizudin }\end{array}$ & $\begin{array}{c}0,1 \\
8\end{array}$ & 0,06 & 0,09 & 0,16 & 0,16 & 0,65 \\
\hline 18 & $\begin{array}{c}\text { Anisa } \\
\text { Hemalia Putri }\end{array}$ & $\begin{array}{c}0,1 \\
2\end{array}$ & 0,09 & 0,12 & 0,20 & 0,20 & 0,73 \\
\hline 19 & $\begin{array}{c}\text { Fairuza } \\
\text { Muntaza } \\
\text { Shakila }\end{array}$ & $\begin{array}{c}0,2 \\
4\end{array}$ & 0,12 & 0,15 & 0,20 & 0,20 & 0,91 \\
\hline 20 & $\begin{array}{c}\text { Farid } \\
\text { Febriansyah }\end{array}$ & $\begin{array}{c}0,1 \\
2\end{array}$ & 0,09 & 0,09 & 0,12 & 0,12 & 0,54 \\
\hline 21 & $\begin{array}{l}\text { Fatimah } \\
\text { Najwati } \\
\text { Azzahra }\end{array}$ & $\begin{array}{c}0,2 \\
4\end{array}$ & 0,09 & 0,09 & 0,16 & 0,16 & 0,74 \\
\hline 22 & $\begin{array}{l}\text { Fatimah } \\
\text { Najwita } \\
\text { Azzahra }\end{array}$ & $\begin{array}{c}0,2 \\
4\end{array}$ & 0,09 & 0,09 & 0,16 & 0,16 & 0,74 \\
\hline 23 & $\begin{array}{c}\text { Kinanti } \\
\text { Anantia Putri }\end{array}$ & $\begin{array}{c}0,1 \\
8\end{array}$ & 0,09 & 0,12 & 0,20 & 0,20 & 0,79 \\
\hline 24 & $\begin{array}{c}\text { Muhammad } \\
\text { Zakky Ibnu } \\
\text { Satria }\end{array}$ & $\begin{array}{c}0,1 \\
8\end{array}$ & 0,06 & 0,09 & 0,16 & 0,12 & 0,61 \\
\hline 25 & Nabil Syafiq & $\begin{array}{c}0,1 \\
2\end{array}$ & 0,09 & 0,09 & 0,12 & 0,16 & 0,58 \\
\hline 26 & $\begin{array}{l}\text { Nabila Arta } \\
\text { Milasari }\end{array}$ & $\begin{array}{c}0,1 \\
8\end{array}$ & 0,09 & 0,09 & 0,16 & 0,16 & 0,68 \\
\hline 27 & $\begin{array}{c}\text { Rizkia } \\
\text { Ramadhani }\end{array}$ & $\begin{array}{c}0,2 \\
4\end{array}$ & 0,12 & 0,09 & 0,08 & 0,12 & 0,65 \\
\hline 28 & Suwindah & $\begin{array}{c}0,3 \\
0\end{array}$ & 0,15 & 0,15 & 0,20 & 0,20 & 1,00 \\
\hline 29 & $\begin{array}{c}\text { Syahira } \\
\text { Anastasia } \\
\text { Putri }\end{array}$ & $\begin{array}{c}0,2 \\
4\end{array}$ & 0,12 & 0,12 & 0,12 & 0,16 & 0,76 \\
\hline 30 & $\begin{array}{c}\text { Zacky } \\
\text { Zakaria }\end{array}$ & $\begin{array}{c}0,1 \\
2\end{array}$ & 0,09 & 0,09 & 0,16 & 0,16 & 0,62 \\
\hline
\end{tabular}

semakin tinggi hasil akhir yang diperoleh maka akan semakin besar peluang untuk menjadi 
siswa terbaik. Berikut hasil perankingan dengan metode Simple Additive Weighting (SAW).

Tabel 5. Tabel Hasil Perankingan

\begin{tabular}{|c|c|c|c|}
\hline No & Nama Siswa & $\begin{array}{l}\text { Hasil } \\
\text { Akhir }\end{array}$ & Ranking \\
\hline 1 & Suwindah & 1.00 & 1 \\
\hline 2 & Indah Pratiwi & 0.97 & 2 \\
\hline 3 & Fairuza Muntaza Shakila & 0.91 & 3 \\
\hline 4 & Ramadhani Septiawan & 0.81 & 4 \\
\hline 5 & Kinanti Anantia Putri & 0.79 & 5 \\
\hline 6 & $\begin{array}{c}\text { M. Maulana } \\
\text { Saifurrahman }\end{array}$ & 0.78 & 6 \\
\hline 7 & Galih Prastiyo & 0.76 & 7 \\
\hline 8 & Syahira Anastasia Putri & 0.76 & 7 \\
\hline 9 & $\begin{array}{c}\text { Kevin Hovandra } \\
\text { Riswandy }\end{array}$ & 0.74 & 8 \\
\hline 10 & Maulisa Darata Putri & 0.74 & 8 \\
\hline 11 & Fatimah Najwati Azzahra & 0.74 & 8 \\
\hline 12 & Fatimah Najwita Azzahra & 0.74 & 8 \\
\hline 13 & Nanda Salsabila & 0.73 & 9 \\
\hline 14 & Anisa Hemalia Putri & 0.73 & 9 \\
\hline 15 & Arwan Sarifuddin & 0.72 & 10 \\
\hline 16 & Nadila Eka Ramadhani & 0.72 & 10 \\
\hline 17 & Romadhoni Fairuz & 0.71 & 11 \\
\hline 18 & Dina Bombom Anto & 0.70 & 12 \\
\hline 19 & Nabila Arta Milasari & 0.68 & 13 \\
\hline 20 & Nabil Abyakta Zufar & 0.67 & 14 \\
\hline 21 & Nabilah Nusaibah & 0.65 & 15 \\
\hline 22 & Sandy Setia Alamsyah & 0.65 & 15 \\
\hline 23 & Zidan A Aizudin & 0.65 & 15 \\
\hline 24 & Rizkia Ramadhani & 0.65 & 15 \\
\hline 25 & Dhani Febriyan & 0.64 & 16 \\
\hline 26 & Ibnu Baihaqi & 0.62 & 17 \\
\hline 27 & Zacky Zakaria & 0.62 & 17 \\
\hline 28 & $\begin{array}{l}\text { Muhammad Zakky Ibnu } \\
\text { Satria }\end{array}$ & 0.61 & 18 \\
\hline 29 & Nabil Syafiq & 0.58 & 19 \\
\hline 30 & Farid Febriansyah & 0.54 & 20 \\
\hline
\end{tabular}

Hasil dari proses normalisasi keputusan berdasarkan perhitungan kriteria. Digambarkan dalam bentuk tabelnya sebagai berikut:
Tabel 6. Tabel Proses Normalisasi

\begin{tabular}{|c|c|c|c|c|c|}
\hline \multirow{2}{*}{ Alternatif } & \multicolumn{5}{|c|}{ Kriteria } \\
\hline & $\mathbf{C}_{1}$ & $\mathbf{C}_{2}$ & $\mathbf{C}_{3}$ & $\mathrm{C}_{4}$ & $\mathrm{C}_{5}$ \\
\hline $\mathrm{A}_{1}$ & 0,6 & 0,6 & 0,6 & 1 & 0,8 \\
\hline $\mathrm{A}_{2}$ & 0,6 & 0,6 & 0,6 & 0,8 & 0,6 \\
\hline $\mathrm{A}_{3}$ & 0,6 & 0,8 & 0,8 & 0,6 & 0,8 \\
\hline $\mathrm{A}_{4}$ & 0,8 & 0,8 & 0,8 & 0,8 & 0,6 \\
\hline $\mathrm{A}_{5}$ & 0,4 & 0,6 & 0,6 & 0,8 & 0,8 \\
\hline $\mathrm{A}_{6}$ & 1 & 0,8 & 1 & 1 & 1 \\
\hline $\mathrm{A}_{7}$ & 0,6 & 0,8 & 0,8 & 0,8 & 0,8 \\
\hline $\mathrm{A}_{8}$ & 0,6 & 0,8 & 0,8 & 1 & 0,8 \\
\hline $\mathrm{A}_{9}$ & 0,6 & 0,8 & 0,8 & 0,8 & 0,8 \\
\hline $\mathrm{A}_{10}$ & 0,8 & 0,4 & 0,6 & 0,8 & 0,6 \\
\hline $\mathrm{A}_{11}$ & 0,6 & 0,4 & 0,6 & 0,8 & 0,8 \\
\hline $\mathrm{A}_{12}$ & 0,6 & 0,6 & 0,6 & 0,8 & 1 \\
\hline $\mathrm{A}_{13}$ & 0,8 & 0,8 & 0,6 & 0,6 & 0,8 \\
\hline $\mathrm{A}_{14}$ & 0,6 & 0,8 & 1 & 0,8 & 1 \\
\hline $\mathrm{A}_{15}$ & 0,6 & 0,8 & 0,6 & 0,8 & 0,8 \\
\hline $\mathrm{A}_{16}$ & 0,6 & 0,4 & 0,6 & 0,8 & 0,8 \\
\hline $\mathrm{A}_{17}$ & 0,6 & 0,4 & 0,6 & 0,8 & 0,8 \\
\hline $\mathrm{A}_{18}$ & 0,4 & 0,6 & 0,8 & 1 & 1 \\
\hline $\mathrm{A}_{19}$ & 0,8 & 0,8 & 1 & 1 & 1 \\
\hline $\mathrm{A}_{20}$ & 0,4 & 0,6 & 0,6 & 0,6 & 0,6 \\
\hline $\mathrm{A}_{21}$ & 0,8 & 0,6 & 0,6 & 0,8 & 0,8 \\
\hline $\mathrm{A}_{22}$ & 0,8 & 0,6 & 0,6 & 0,8 & 0,8 \\
\hline $\mathrm{A}_{23}$ & 0,6 & 0,6 & 0,8 & 1 & 1 \\
\hline $\mathrm{A}_{24}$ & 0,6 & 0,4 & 0,6 & 0,8 & 0,6 \\
\hline $\mathrm{A}_{25}$ & 0,4 & 0,6 & 0,6 & 0,6 & 0,8 \\
\hline $\mathrm{A}_{26}$ & 0,6 & 0,6 & 0,6 & 0,8 & 0,8 \\
\hline $\mathrm{A}_{27}$ & 0,8 & 0,8 & 0,6 & 0,4 & 0,6 \\
\hline $\mathrm{A}_{28}$ & 1 & 1 & 1 & 1 & 1 \\
\hline $\mathrm{A}_{29}$ & 0,8 & 0,8 & 0,8 & 0,6 & 0,8 \\
\hline $\mathrm{A}_{30}$ & 0,4 & 0,6 & 0,6 & 0,8 & 0,8 \\
\hline
\end{tabular}


Nilai terbesar ada pada $\mathrm{V}_{28}$ sehingga alternatif $A_{28}$ (Siswa ke - 28) adalah alternatif yang terpilih sebagai alternatif yang terbaik dengan hasil akhir 1,00.Namun pada kasus ini alternatif yang terbaik adalah beberapa siswa yang mendapatkan nilai pembobotan cukup pada setiap kriteria.

\section{KESIMPULAN}

Kesimpulan dari penelitian ini adalah sebagai berikut:

- Dari perhitungan dengan menggunakan metode Simple Additive Weighting, dengan mengacu pada penilaian berdasarkan kriteria yang sudah ditentukan yaitu berakhlak baik, aktif di dalam kelas, nilai raport tertinggi, absensi kehadiran, dan bertanggung jawab, maka terpilih siswa terbaik pertama yang bernama Suwindah dengan nilai yang diperoleh sebesar 1,00.

- Dari hasil analisis perhitungann dengan menggunakan metode Simple Additive Weighting dan dari hasil kuesioner penilaian siswa yang terdiri dari kriteria berakhlak baik, aktif di dalam kelas, nilai raport tertinggi, absensi kehadiran, dan bertanggung jawab, siswa bernama Suwindah mendapatkan nilai sempurna.

- Dengan demikian, untuk menentukan siswa terbaik tidak cukup hanya dengan penilaian akademinnya saja tetapi juga memperhitungkan penilaian nonakademiknya.

\section{SARAN}

- $\quad$ Sistem yang penulis buat dapat dikembangkan dengan metode yang berbeda atau mengkombinasikan metode SAW dengan metode lainnya.

- Agar hasil sisstem keputusan lebih baik dapat diimplementasikan dengan bentuk aplikasi berbasis mobile ataupun web dengan tampilan userfriendly.

\section{DAFTAR PUSTAKA}

[1] R. P. Pratama, I. Werdiningsih, and I. Puspitasari, "Sistem Pendukung Keputusan Pemilihan Siswa Berprestasi di Sekolah Menengah Pertama dengan Metode VIKOR dan TOPSIS," J. Inf.
Syst. Eng. Bus. Intell., vol. 3, no. 2, pp. 113-121, 2017.

[2] R. Pradita and N. Hidayat, "Sistem Pendukung Keputusan Pemilihan Guru Berprestasi Menggunakan Metode PROMETHEE," J. Sains Dan Seni Pomits, vol. 2, no. 1, pp. 63-68, 2013.

[3] I. G. B. Subawa, I. M. A. Wirawan, and I. M. G. Sunarya, "PEMILIHAN PEGAWAI TERBAIK MENGGUNAKAN METODE SIMPLE ADDITIVE WEIGHTING ( SAW ) DI PT TIRTA JAYA ABADI SINGARAJA," vol. 4, 2015.

[4] M. Elistri, J. Wahyudi, and R. Supardi, "Penerapan Metode Saw Dalam Sistem Pendukung Keputusan Pemilihan Jurusan Pada Sekolah Menengah Atas Negeri 8 Seluma," $J$. Media Infotama Penerapan Metod. SAW ... ISSN, vol. 10, no. 2, pp. 1858-2680, 2014.

[5] Elistri, M., Wahyudi, J., \& Supardi, R. (2014). Penerapan Metode Saw Dalam Sistem Pendukung Keputusan Pemilihan Jurusan Pada Sekolah Menengah Atas Negeri 8 Seluma. Jurnal Media Infotama Penerapan Metode SAW... ISSN, 10(2), 1858-2680.

[6] Frieyadie. (2016). DALAM SISTEM PENDUKUNG KEPUTUSAN PROMOSI, (1), 37-45. 